\title{
Design Simulation Queue Cake Shop With Lamport's Bakery Algorithm
}

\author{
${ }^{1}$ Roberth Ricki Y. Manaha, ${ }^{2}$ Janeman Summah \\ 1,2 Teknik Informatika, Universitas Kristen Indonesia Maluku \\ Email : roberth01@gmail.com ${ }^{1}$, janeman04@gmail.com ${ }^{2}$
}

\begin{tabular}{l}
\hline Keywords \\
\hline Lamport's Bakery Algorithm, \\
Concurrency \\
Mutual exclusion
\end{tabular}

\begin{abstract}
Mutual exclusion is one of the mechanisms that can be used to solve concurrency problems in the operating system. In the operating system, there are resources that cannot be shared at the same time, such as printers. These kinds of resources are called critical resources. Programs that use critical resources are called entering critical regions/sections. Programmers cannot rely on the operating system to understand and enforce these limits. The mutual exclusion settlement process was submitted by several experts. One of them is Lamport with a method known as Lamport's Bakery Algorithm. The work process of Lamport's Bakery Algorithm starts from the buyer entering the store and receiving the sequence number. If there is a waiter who is idle (not being / will serve other buyers), then the buyer directly asks for service from the waiter. If not, then the buyer sits in the buyer's waiting area and waits until his turn. Shoppers who have finished being served out of the store and waiters who are idle serve the lowest numbered buyers who are waiting at the waiting place of the buyer.
\end{abstract}

\section{INTRODUCTION}

Mutual exclusion is a guarantee that only one process accesses resources at a time interval. Mutual exclusion must be guaranteed because not all resources can be used by more than one process at a time, for example on printing to a printer [1]. To ensure mutual exclusion, the operating system as a resource manager in the computer can implement several solutions, one of which is a solution known as Lamport's Bakery algorithm[2].

Lamport solution is often referred to as a solution baker (Bakery algorithm). This algorithm is based on the scheduling in cake, ice cream, or meat stores. Upon entering the store, each buyer receives a number. The lowest numbered buyers are served first. Unfortunately, Bakery's algorithm cannot guarantee the two processes do not receive the same number. In this case, the process with the lowest name, is served first. Because the process names are unique and totally sorted, it is a deterministic algorithm [3], [4].

\section{METHOD}

Lamport's bakery algorithm is a computer algorithm suggested by computer expert Leslie Lamport, who wants to improve the convenience of using shared resources in many threads in the context of mutual exclusion [5], [6]. In computer science, it is common for multiple threads to access the same resources simultaneously. Data corruption can occur if two or more threads try to write to the same memory location, or if one thread reads a memory location before another process finishes writing it. Lamport's bakery algorithm is one of many mutual exclusion algorithms designed to prevent concurrent threads when entering critical sections of code to eliminate the risk of data corruption [5]-[8].

Lamport solution is called bakery algorithm solution. The algorithm is based on Penjadualan in cake, ice cream, or meat stores. Upon entering the store, each buyer receives a number. The lowest numbered buyers are served first.

The working steps of lamport algorithm can be described as follows:

1. Shoppers enter the store and receive a sequence number.

2. If there is a waiter who is idle (not being / will serve other buyers), then the buyer directly asks for service from the waiter.

3. If not, then the buyer sits in the buyer's waiting area and waits until his turn.

Jurnal Info Sains : Informatikan dan Sains is licensed under a Creative Commons Attribution-Non Commercial 
a) Shoppers who have finished being served out of the store and waiters who are idle serve the lowest numbered buyers who are waiting at the buyer's waitingplace. The assumptions used by Lamport are:

b) Only one buyer enters within a certain time.

c) The number of items of each buyer is recorded, but the item type is not noticed.

Lamport simulates a bakery with a numbering machine at the entrance so that each customer is given a unique number [4], [9]. The number will increase by one when the customer enters the store. A global counter shows the number of customers who have been served. All other customers will have to wait in line until the baker finishes serving the customer and the next number will be displayed. When the customer has finished being served and has revoked the number, then the clerk adds the number so that it allows other customers to be served [10]. Customers must take another number from the numbering machine to be able to shop again at the bakery .

The algorithm used to design lamport's Bakery Algorithm simulation software can be divided into several parts, among others:

1. Timing algorithm.

2. The algorithm of timing the arrival of the buyer.

3. Turn checking algorithm.

4. Empty seat checking algorithm.

5. Door-to-door checking algorithm.

6. The algorithm of setting the buyer's image so that it does not overlap.

\section{RESULTS OF DISCUSSION}

Lamport's bakery algorithm is a solution proposed by Lamport to solve the problem of mutual exclusion for $\mathrm{n}$ process. Lamport's bakery algorithm implements a FIFO (First In First Out) queue process algorithm which means first-time buyers will have a smaller number. Smaller numbered buyers will be served by the waiter in advance. Meanwhile, the queue model applied by Lamport's bakery algorithm is the MQMS (Multi Queue Multi Server) queue model which means that there are $\mathrm{n}$ queue fruits that will be served by $\mathrm{n}$ waiters, where $\mathrm{n}$ is worth more than one.

\subsection{Software Assumptions}

The assumptions used by Lamport's bakery algorithm simulation software are as follows:

1. Only one buyer enters within a certain time. In this case it means each buyer has a time difference.

2. The purchase amount of each buyer is recorded but the item type is not considered.

3. The smallest unit of time taken is the minute unit. This means that the time in the software will move 1 minute every time the computer moves $n$ milliseconds.

4. The number of cashiers is limited to a maximum of 5 pieces and a minimum of 2 pieces.

5. The number of waiting seats is limited to 10 pieces.

6. The type of cake is limited to 4 types only.

7. The number of cake items that can be stored is a maximum of 4 digits of positive integers. This number of items represents the number of resources available in an app.

8. The number of items has a critical limit that can be inputted manually, with a minimum limit of 5 pieces and a maximum of 20 pieces. This critical limit represents the remaining resources available in the application. If the application has reached a critical point, it will run slower, while the application provides the necessary resources.

The things that will be recorded in this simulation are as follows:

1. Long time buyers waiting in the waiting place (queue).

2. Long time buyers choose cakes.

3. Long time buyers make payments.

The main view of this simulation software can be seen in the following image:

1. Display at a time when there are no buyers. 


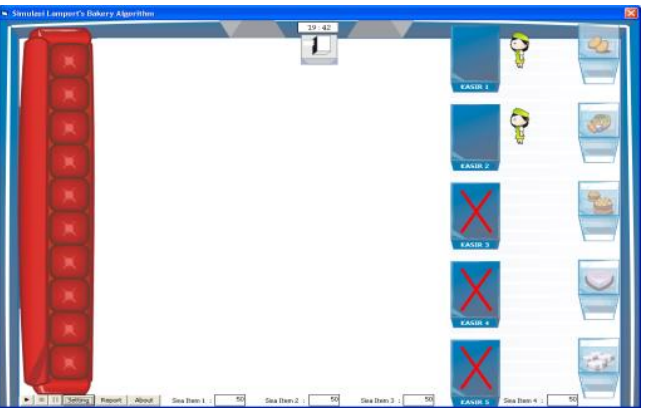

Figure 1 Display when the waiter is idle

When there are no buyers, the waiter will stand waiting for the customer's arrival.

2. Display when there are buyers.

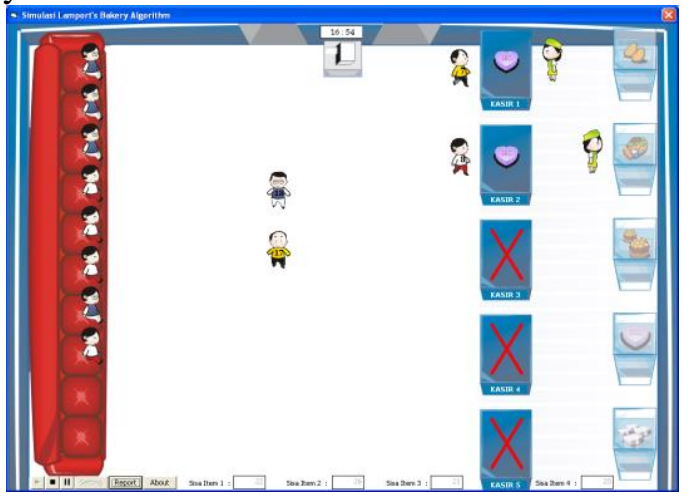

Figure 2 Display when there are buyers in the system

The working steps of lamport algorithm can be described as follows:

1. Shoppers enter the store and receive a sequence number.

2. If there is a waiter who is idle (not being / will serve other buyers), then the buyer directly asks for service from the waiter.

3. If not, then the buyer sits in the buyer's waiting area and waits until his turn.

4. Shoppers who have finished being served out of the store and waiters who are idle serve the lowest numbered buyers who are waiting at the waiting place of the buyer. The assumptions used by Lamport are:

a) Only one buyer enters within a certain time.

b) The number of items of each buyer is recorded, but the item type is not noticed.

Lamport simulates a bakery with a numbering machine at the entrance so that each customer is given a unique number. The number will increase by one when the customer enters the store. A global counter shows the number of customers who have been served. All other customers will have to wait in line until the baker finishes serving the customer and the next number will be displayed. When the customer has finished being served and has revoked the number, then the clerk adds the number so that it allows other customers to be served. Customers must take another number from the numbering machine to be able to shop again at the bakery.

\section{CONCLUSION}

The software can simulate Lamport's Bakery Algorithm clearly and interactively, so that it can be used as an illustration of mutual exclusion problems for the N-process. The software displays a table of simulation process data containing the details of the simulation process that can be used to assist the observation of the simulation process. The software can be used to compare several different circumstances by setting the initial state of the simulation process through the 'Setting' facility.

\section{REFERENCE}

[1] M. Tawil, "Pembelajaran Berbasis Simulasi Komputer untuk Meningkatkan Keterampilan Berpikir Kreatif Mahasiswa," J. Ilmu Pendidik., vol. 20, no. 1, 2014.

Jurnal Info Sains : Informatikan dan Sains is licensed under a Creative Commons Attribution-Non Commercial 
[2] V. Dyseryn, R. Van Glabbeek, and P. Höfner, "Analysing mutual exclusion using process algebra with signals," in Electronic Proceedings in Theoretical Computer Science, EPTCS, 2017, vol. 255, doi: 10.4204/EPTCS.255.2.

[3] J. Susetyo and S. R. Nasution, "ANALISIS SISTEM ANTRIAN MULTIPLE CHANNEL UNTUK KAPASITAS TERBATAS,” J. Ilm. Tek. Ind., vol. 5, no. 3, 2018, doi: 10.24912/jitiuntar.v5i3.2107.

[4] H. Oktaviyanty, K. Dwidayati, and A. Agoestanto, "Optimasi Sistem Antrian pada Pelayanan Servis Sepeda Motor Berdasarkan Model Tingkat Aspirasi Studi Kasus Bengkel Ahass Handayani Motor (1706) Semarang," UNNES J. Math., vol. 7, no. 2, 2018.

[5] S. Nakano and T. Tsuchiya, "Method and case study of model checking concurrent systems that use unbounded timestamps," 2017, doi: 10.1109/PRDC.2017.50.

[6] J. Aranda, I. Zabalza, E. Llera-Sastresa, S. Scarpellini, and A. Alcalde, "Building energy assessment and computer simulation applied to social housing in Spain," Buildings, vol. 8, no. 1, 2018, doi: 10.3390/buildings8010011.

[7] Y. Li, X. Zhang, T. Qiu, J. Zeng, and P. Hu, "A Distributed TDMA Scheduling Algorithm Based on Exponential Backoff Rule and Energy-Topology Factor in Internet of Things," IEEE Access, vol. 5, 2017, doi: 10.1109/ACCESS.2017.2758340.

[8] L. Serlina, "Analisis Sistem Antrian Pelanggan Bank Rakyat Indonesia (Bri) Cabang Bandar Lampung Menggunakan Model Antrian Multi Channel-Single Phase," 2018.

[9] A. Purba and I. Taufik, "Penerapan Sistem Antrian Registrasi dengan Metode Multi ChannelMulti Phase," J. Teknol. dan Ilmu Komput. Prima, vol. 1, no. 2, 2018, doi: 10.34012/jutikomp.v1i2.244.

[10] S. V. Lyulin et al., "Computer Simulation of Asphaltenes," Pet. Chem., vol. 58, no. 12, 2018, doi: 10.1134/S0965544118120149. 